\title{
Water Pollution and Ecosystem Conservancy
}

\author{
Ișık Kabdașlı ${ }^{1}$ - Vassilios A. Tsihrintzis ${ }^{2}$
}

Published online: 8 August 2016

(C) Springer International Publishing Switzerland 2016

EWRA organizes an international conference every two years. Up to now, the organization was in various European countries. For the first time, a city at the boundary of Europe was selected for the EWRA Congress. Istanbul is the bridge between Europe and Asia, thus the city selection reflected the willingness for expansion of EWRA towards Asia and other continents, since this organization has become a truly international association with members from all countries of the world. Furthermore, the Congress offered the opportunity to European scientists to spread to other countries of the world the European approaches in Water Resources Management, including the innovative paradigm of the Water Framework Directive.

The 9th Congress of EWRA comprised the following six specialized conferences:

I. Hydrological Processes and Evolving Hazards

II. Geo-information and Water Resources

III. Technological Advances in Water Distribution, Purification and Desalination

IV. Water Pollution and Ecosystems Conservancy

V. Multicriteria Sustainability of Water Systems

VI. Social, Political, Institutional and Legislative Aspects

This special issue of Environmental Processes includes selected papers presented in the 9th World Congress of the European Water Resources Association (EWRA), which was held in Istanbul, Turkey, 10-13 June 2015. The general title of the congress was «Water Resources Management in a Changing World: Challenges and Opportunities».

Vassilios A. Tsihrintzis

tsihrin@central.ntua.gr; tsihrin@survey.ntua.gr; tsihrin@otenet.gr

Ișık Kabdaşlı

kabdasli@itu.edu.tr

1 Environmental Engineering Department, Civil Engineering Faculty, İstanbul Technical University, Ayazağa Campus, 34469 İstanbul, Turkey

2 Centre for the Assessment of Natural Hazards and Proactive Planning \& Laboratory of Reclamation Works and Water Resources Management, School of Rural and Surveying Engineering, National Technical University of Athens, 9 Iroon Polytechniou St., Zografou, 15780 Athens, Greece 
As seen, these six conferences covered a wide range of modern topics on water resources and the environment. Engineers and scientists from forty nine countries presented contributions in oral and poster form. High quality papers were presented, which have significantly contributed to the multidisciplinary and global context of the Congress. In the discussions which took place, participants from various disciplines and countries interacted, leading to significant results regarding the formulation of future approaches and procedures in the areas of water resources engineering and management. As a notice, the next EWRA congress, the 10th World Congress on Water Resources and Environment, will be held in Athens, 5-9 July 2017 (http://ewra2017.ewra.net).

This special issue of Environmental Processes, with the title "Water Pollution and Ecosystems Conservancy”, was guest-edited by professors: Ișık Kabdașlı (İstanbul Technical University, İstanbul, Turkey) and Vassilios A. Tsihrintzis (National Technical University of Athens, Athens, Greece). Originally, 31 papers presented at the conference were pre-selected for peer review and possible publication in the journal. The authors were notified to expand the paper and submit it for peer review. Finally, the following 11 papers made it to publication. The topics dealt in these papers are briefly presented below.

Khan et al. (2016) investigated the diversity of microorganisms in tap-water in Glasgow, Scotland, and the occurrence of certain antibiotic resistance genes and gene-transfer mechanisms, and found that antibiotic resistant bacteria exist in the distribution system and also genes which can aid in the dispersion of resistance genes. The findings indicate that further investigations should be made to assess the risks to public health.

Colombani et al. (2016b) studied the climate change induced alteration of water quality of the shallow groundwater system of the Po River delta in Italy. Data were collected and used to calibrate a density-dependent reactive transport model and run a series of numerical scenarios following Intergovernmental Panel on Climate Change 2014 projections on sea level rise and climate change. Results of the model indicate an increase of heavy metals export toward surface waters, indicating that surface water quality could be negatively affected by climate change.

Ramos et al. (2016) assessed the ecological risk associated with projected/future flow alteration in the Portuguese Guadiana River Basin, based on five climate change scenarios. Hydrological impacts were modeled with the Temez hydrological model. Ecological impacts were assessed using the ecological risk due to flow alteration (ERFA) screening method. Colour-coded risk classification maps were produced for the river reaches. The ecological risk of the Guadiana River Basin was found to increase based on the projected climate change scenarios which predict increases in temperature and decreases in precipitation.

Latinopoulos et al. (2016) describe existing stressors on Greek lakes and their impacts, based on an extensive dataset from twelve natural lakes, using several metrics and ecohydrological characteristics. The results indicate impacts on water quality and quantity affecting lake functions, and extended eutrophication due to hydromorphological alterations and particularities of the Mediterranean climate. Management practices are proposed.

Al-Faraja et al. (2016) present the Diyala basin, one of the most water-stressed transboundary river basins shared between Iraq and Iran, as a case study of efficient water allocation for sustainable irrigated agriculture. Climate change projections in this area indicate lower precipitation and higher rates of potential evapotranspiration. In addition, irrigation demands are growing. Climate change impacts were evaluated with the use of a mathematical model, which showed reduction of annual runoff from 14 to $30 \%$, indicating considerable water deficits. Plausible scenarios were tested to reduce irrigation water demand while maintaining a healthy agricultural sector. 
Colombani et al. (2016a) tested natural zeolites as soil conditioners to diminish nutrient leaching and increase irrigation efficiency in a 6-ha experimental site which was monitored for two years. The site included three control parcels which were cultivated and irrigated according to the traditional way, two parcels amended with coarse-grained natural zeolite at two different zeolite/soil ratios (5 and $15 \mathrm{~kg} / \mathrm{m}^{2}$ ); and two parcels amended with fine-grained zeolite $\left(7\right.$ and $\left.10 \mathrm{~kg} / \mathrm{m}^{2}\right)$. Monitoring was continuous and included soil electrical conductivity, temperature and volumetric water content, while an on-site meteorological station provided the needed meteorological parameters. Experimental results indicated an increase of soil water availability in the zeolite-amended parcels with respect to the control ones, particularly for those amended with $10 \mathrm{~kg} / \mathrm{m}^{2}$ of fine-grained material. In addition, after an intense rainfall, this parcel showed an increased field capacity and reduced percolation.

Tigkas et al. (2016) compared the effectiveness and efficiency of three evolutionary algorithms, i.e., the Shuffled Complex Evolution (SCE), the Genetic Algorithms (GA) and the Evolutionary Annealing-Simplex (EAS), in the calibration of the Medbasin-D daily conceptual rainfall-runoff model, and present an improved calibration module which was applied in a watershed in Crete island, Greece. The effectiveness of SCE and EAS were equally good, while that of GA was slightly worse, but the computational efficiency of GA was better than those of SCE and EAS. Finally, based on the simulated hydrographs, Medbasin-D produced equally successful results with all tested optimisation methods.

Ali et al. (2016) described the development and testing of a new model (NCM) for diffuse source pollution which integrates a complex distributed catchment model (HSPF) with a model for contaminant transport (SWAT). Testing took place in three Irish catchments where the new model was calibrated and validated, and its outputs were compared with those of SWAT and HSPF. NCM gave good results in terms of flow and phosphorus modelling, and was generally better than SWAT or HSPF alone.

Kitsikoudis et al. (2016) studied sediment incipient motion under turbulent flow conditions using fuzzy logic theory. They used two approaches, i.e., the conventional fuzzy regression analysis and a goal programming-based fuzzy regression with very promising results.

Theologou et al. (2016) tested the use of high-resolution, multitemporal remote sensing data for water quality estimation. They used in-situ measurements for key water quality parameters in lake Karla, central Greece, to establish relations with the satellite data. Results showed a high correlation rate $\left(\mathrm{r}^{2}>89 \%\right)$ for chlorophyll-a when using a linear regression model. The proposed methodology provides a low-cost water quality monitoring system.

Kopasakis et al. (2016) used a three-dimensional hydrodynamic model to study the effects of inflows, wind action and the Coriolis force on the water circulation and the horizontal dispersion of lake Karla, central Greece. The horizontal dispersion rate was found higher in the central region of the lake and not influenced by the presence of the inflow from Pinios River and the Coriolis action.

\section{References}

Al-Faraja FAM, Tigkas D, Scholz M (2016) Irrigation efficiency improvement for sustainable agriculture in changing climate: A transboundary watershed between Iraq and Iran. Environ Process. doi:10.1007/s40710016-0148-0

Ali I, Bruen M (2016) Methodology and application of the combined SWAT-HSPF model. Environ Process. doi: $10.1007 / \mathrm{s} 40710-016-0167-\mathrm{x}$ 
Colombani N, Di Giuseppe D, Faccini B, Ferretti G, Mastrocicco M, Coltorti M (2016a) Estimated water savings in an agricultural field amended with natural zeolites. Environ Process. doi:10.1007/s40710-016-0151-5

Colombani N, Dinelli E, Mastrocicco M (2016b) Trend of heavy metal release according to forecasted climate change in the Po delta. Environ Process. doi:10.1007/s40710-016-0146-2

Khan S, Knapp CW, Beattie TK (2016) Antibiotic resistant bacteria found in municipal drinking water. Environ Process. doi:10.1007/s40710-016-0149-z

Kitsikoudis V, Spiliotis M, Hrissanthou V (2016) Fuzzy regression analysis for sediment incipient motion under turbulent flow conditions. Environ Process. doi:10.1007/s40710-016-0154-2

Kopasakis K, Laspidou C, Spiliotopoulos M, Kofinas D, Mellios N (2016) Numerical investigation of wind driven circulation and horizontal dispersion in the surface layer of a re-flooded shallow lake. Environ Process. doi:10.1007/s40710-016-0165-Z

Latinopoulos D, Ntislidou C, Kagalou I (2016) Multipurpose plans for the sustainability of the Greek Lakes: emphasis on multiple stressors. Environ Process. doi:10.1007/s40710-016-0152-4

Ramos V, Maia R, Formigo N, Oliveira B (2016) Assessment of ecological risk based on projected hydrological alteration. Environ Process. doi:10.1007/s40710-016-0164-0

Theologou I, Kagalou I, Papadopoulou MP, Karantzalos K (2016) Multi-temporal high resolution satellite chlorophyll- $\alpha$ mapping of lake Karla. Environ Process. doi:10.1007/s40710-016-0163-1

Tigkas D, Christelis V, Tsakiris G (2016) Comparative study of evolutionary algorithms for the automatic calibration of the Medbasin-D conceptual hydrological model. Environ Process. doi:10.1007/s40710-0160147-1 